\title{
Anti-trypsin and antihypertensive activity of protein extracts from Nigella sativa seeds
}

\author{
Bushra Javaid $^{1}$, Nadia Majeed ${ }^{1}$ Farah Deeba ${ }^{1,3}$, Amna Muhammad $^{1}$, M. Sheeraz Ahmad ${ }^{1}$, \\ Ata Ur Rehman ${ }^{2}$, Christopher Blanchard ${ }^{2}$ and S. M. Saqlan Naqvi ${ }^{1, *}$ \\ ${ }^{1}$ University Institute of Biochemistry \& Biotechnology, PMAS- Arid Agriculture University, Rawalpindi 46300, Pakistan; \\ ${ }^{2}$ School of Biomedical Sciences, Charles Sturt University, Wagga Wagga, NSW 2650, Australia; ${ }^{3}$ Department of \\ Biochemistry and Biotechnology, The Women University, Multan, Pakistan \\ *Corresponding author's e-mail: saqlan@uaar.edu.pk
}

\begin{abstract}
Protease inhibitors (PIs) are a ubiquitous, diverse group of molecules present in multiple forms in all organisms. These inhibitors inactivate proteases from predators/pathogens in addition to regulating intracellular proteolysis. In addition to intracellular localization, storage organs of plants are also a potential site of protease inhibitors. Proteins with trypsin inhibitory activity were isolated from Nigella sativa seed extracts by ammonium sulphate precipitation. Extraction conditions were optimized by choosing an optimum solvent, temperature and incubation period. The highest inhibitory activity of protein extracts was achieved by using $50 \mathrm{mM}$ Tris buffer as solvent and overnight incubation of the suspension at $4^{\circ} \mathrm{C}$. The crude seed extract fractionated at $60 \%$ ammonium sulphate concentration exhibited highest trypsin inhibitory activity, i.e., $60.15 \pm$ $2.95 \%$, which was comparable to soybean trypsin inhibitor used as positive control. Ammonium sulphate precipitation of crude extract yielded 39.83-fold purification. Partially purified trypsin inhibitor exhibited $2.39 \pm 0.23 \mathrm{TIU} \mathrm{mg}^{-1}$. Additionally, Nigella sativa protein extracts were also investigated for their health-promoting effects against two important proteases, $\alpha$ Dipeptidyl peptidase-IV (DPP-IV) and angiotensin-converting enzyme (ACE). Highest inhibitory activity against ACE was shown by the crude extract of $N$. sativa. Among AS fractions, 30\% ammonium sulphate concentration exhibited highest inhibition activity against ACE and DPP-IV. Our results suggest that the widely believed role of $N$. sativa in control of hypertension may at least be partially shared by inhibition of ACE. This is the first study conducted to evaluate the biological activity of $N$. sativa protein extracts suggesting a potential use of $N$. sativa proteins in management of hypertension as well as an important source of trypsin inhibitor. Further identification, purification and characterization of different bioactive compounds from $N$. sativa are being carried out.
\end{abstract}

Keywords: Nigella sativa, Trypsin inhibitor, Dipeptidyl peptidase IV, angiotensin-converting enzyme, antihypertensive.

\section{INTRODUCTION}

Plants encounter various environmental stresses frequently throughout their life span influencing their growth and development. Life and development of plants has been greatly influenced by these stresses at the morphological and physiological level to cellular and molecular level. (Kidrič et al., 2014). Plants have evolved a multi-layered immune system to cope with environmental stresses and counteract them by preformed chemical and physical barriers constituting their first line of defense. (Slavokhotova et al., 2014). Under stress conditions, plants retaliate by two different ways, i.e., by degrading damaged or non-functional endogenous proteins resulting from overproduction of reactive oxygen species, or by expression of certain proteins that helps plants to withstand the effect of stress (Vierstra, 1996). Plants inhibit protein hydrolyzing enzymes of herbivores and pathogenic microorganisms by producing various protein and non-protein molecule, in addition to regulating endogenous proteases (Polya, 2003).

Protease inhibitor (PI) proteins are found mainly in seeds and tubers although aerial parts also contain these proteins (De Leo et al., 2002). Storage organs of plants attract pests and pathogens due to their high nutritional value (Christeller, 2005), but on the other hand are protected by PIs which may contribute up to $10 \%$ of the total storage proteins (Ryan, 1990). It is well recognized that PIs can delay the proteolytic degradation of many food products by constraining the action

Javaid, B., N. Majeed, F. Deeba, A. Muhammad, M.S. Ahmad, A.U. Rehman, C. Blanchard and S.M.S. Naqvi1. 2021. Anti-trypsin and antihypertensive activity of protein extracts from Nigella sativa seeds. Pak. J. Agri. Sci.58:1237-1243.

[Received 12 Feb 2020; Accepted 7 Jun 2021; Published (online) 21 Sep 2021] 
of extrinsic and intrinsic proteases in the process of food preservation and adept to increase their half-life (Reppond and Babbitt, 1993). Induction of PIs has also been observed in response to biotic and abiotic stresses (Fan and Guo-Jiang, 2005; Laskowski Jr and Kato, 1980). PIs are also well known to have potential applications in the treatment of many human diseases such as cancer, high blood pressure, and AIDS (Johnson and Pellecchia, 2006). Therefore, PIs continue to gain the attention of scientists due to their usage in medicine and biotechnology.

Structurally, protease inhibitors are divided into various classes based on the type of protease they inhibit, including cysteine-, serine-, Aspartate- and metallo-proteases (Abbenante and Fairlie, 2005). However, serine protease inhibitors are the largest and extensively studied PIs in plants which include trypsin inhibitors (Di Cera, 2009). A lot of protease inhibitors have been extracted, identified and characterized from several plants (Meulenbroek et al., 2012). However, there is no report about detection of proteinaceous protease inhibitors from Nigella sativa, an annual herb belonging to Ranunculaceae family. It is native to countries bordering the Mediterranean Sea, Iran, Pakistan and India. $N$. sativa seeds have been used traditionally for treating various diseases for centuries. These are rich source of bioactive compounds and proteins. Several bioactive compounds with bactericidal, fungicidal, immunosuppressive and antiinflammatory activities have been isolated from $N$. sativa seeds (Ahmad et al., 2013). Keeping in mind the therapeutic potential of $N$. sativa seeds, present study was designed to evaluate bioactive potential of protein extracts obtained from $N$. sativa seeds.

\section{MATERIALS AND METHODS}

\section{PLANT MATERIAL}

$N$. sativa seeds were purchased from local market of Wagga Wagga, NSW, Australia.

Choice of Solvent for Extraction of Inhibitor: Finely ground $N$. sativa seeds were defatted twice by using n-hexane (1:3 $\mathrm{w} / \mathrm{v})$. After extracting with $\mathrm{n}$-hexane for 5 hours, flour was separated by Buchner funnel under vacuum and air dried under fume hood overnight. Three aqueous solvents [50 mM Acetic acid, $50 \mathrm{mM}$ Tris $\mathrm{HCl} \mathrm{pH} 8$ and $100 \mathrm{mM} \mathrm{NaOH}$ ] were employed for extraction of inhibitor(s) from $N$. sativa defatted seed flour. The flour was resuspended in solvents $(1: 10 \mathrm{w} / \mathrm{v})$ and incubated at room temperature (RT) for 3 hours with continuous stirring. Suspensions were centrifuged at $25,000 \mathrm{~g}$ for 30 minutes and clear supernatant was used for performing inhibition assay.

Optimization of Extraction Conditions: To evaluate effect of temperature and extraction time, seed flour was resuspended in selected solvent and incubated at either RT or $4^{\circ} \mathrm{C}$ for 5 hours or overnight with continuous stirring. Resultant suspensions were centrifuged at 25,000 $\mathrm{g}$ for 30 minutes and clear supernatant was used for performing inhibition assay.

Preparation of Crude Extract: Crude extract (CE) of $N$. sativa was obtained by treating defatted flour in $50 \mathrm{mM}$ Tris $\mathrm{HCl}$ buffer, $\mathrm{pH} 8$ overnight at $4^{\circ} \mathrm{C}$ with continuous stirring. Supernatant obtained after centrifugation at $25,000 \mathrm{~g}$ for 30 min at $4^{\circ} \mathrm{C}$ was filtered using Whatmann filter paper No.1. Clear solution obtained by centrifugation and filtration was designated as crude extract.

Ammonium Sulphate Precipitation: N. sativa seed proteins were fractionated by ammonium sulphate (AS) precipitation. Precipitation was carried out to split crude extract into three fractions i.e., $30 \%, 60 \%$ and saturated AS fraction. For $30 \%$ saturation appropriate amounts of solid ammonium sulphate was slowly adding by constant stirring, and incubated for 2 hours at RT. Pellet obtained after centrifugation at 20,000 g for $15 \mathrm{~min}$ at $25^{\circ} \mathrm{C}$, was dissolved in minimal amount of extraction buffer and dialyzed against extraction buffer for 24 hours by changing the buffer three to four times. This preparation was designated as $30 \% \mathrm{AS}$ fraction (AS-30). The supernatant obtained from AS-30 was used to obtain $60 \%$ AS fraction (AS-60) by further addition of calculated amount of solid ammonium sulphate. Precipitate and supernatant were again collected and processed in a similar way as already described. Saturated AS fraction (AS-Sat.) was obtained by adding ammonium sulphate to supernatant recovered after AS-60. Pellets obtained by AS-60 and saturated AS-Sat. were dissolved in minimal volume of extraction buffer and dialyzed against extraction buffer for 24 hours by changing the buffer three to four times.

Protein Estimation: Protein content was estimated by using Pierce ${ }^{T M}$ BCA (Bicinchoninic acid) Protein Assay kit by following instructions mentioned in the manufacturer's protocol (Thermo Fisher Scientific catalogue number 23227). Bovine Serum Albumin (BSA) standard and samples were diluted using $50 \mathrm{mM}$ Tris $\mathrm{HCl} \mathrm{pH}$ 8. Standard curve was obtained by plotting concentration of protein standards versus absorbance values. Concentration of protein samples was determined by using standard curve.

Protease Inhibition Assays: Crude extract and protein fractions obtained by 30\%, 60\% and saturated ammonium sulphate precipitation were evaluated for protease inhibition. Inhibition assays were performed with Trypsin, Chymotrypsin, Dipeptidyl peptidase-IV (DPP-IV) and Angiotensin converting enzyme (ACE). Trypsin and Chymotrypsin inhibition assays were performed by following the protocol developed by Kollipara and Hymowitz (1992) with few modifications.

Trypsin inhibition assay: Trypsin inhibition assay utilizes esterolytic activity of trypsin towards its synthetic substrate TAME ( $\mathrm{N} \alpha$-Tosyl L-arginine methyl ester). Trypsin inhibition activity was determined using $10 \mathrm{mM}$ TAME (prepared freshly in $50 \mathrm{mM}$ Tris $\mathrm{HCl} \mathrm{pH} \mathrm{8.1).} 1 \mathrm{mM} \mathrm{HCl}$ was used to prepare bovine trypsin solution $(20 \mu \mathrm{g} / \mathrm{ml}) .100 \mu \mathrm{L}$ of 
crude extract, 30\%, $60 \%$ and saturated ammonium sulphate (AS) fractions $(1 \mathrm{mg} / \mathrm{mL})$ were added to $710 \mu \mathrm{L}$ of assay buffer, mixed with $90 \mu \mathrm{L}$ of trypsin solution and left for 12 min at RT. $200 \mu \mathrm{L}$ of substrate was added to pre-incubated contents, mixed quickly and absorbance was immediately monitored at $247 \mathrm{~nm}$ for 6 minutes. Soybean trypsin inhibitor was used as positive control. Trypsin inhibitory activity was calculated as trypsin inhibition unit (TIU) per milligram protein content of extract as follows

$$
\mathrm{TIU} / \mathrm{mg}=\frac{\left[\left(\frac{\mathrm{T} \Delta \mathrm{A} 247}{\min }-\frac{\mathrm{I} \Delta \mathrm{A} 247}{\min }\right) \times 1000\right]}{540 \times \text { protein content }(\mathrm{mg})}
$$

Where trypsin activity is represented by $\mathrm{T} \Delta \mathrm{A}_{247} / \mathrm{min}$ in the absence of inhibitor. $\mathrm{I} \Delta \mathrm{A}_{247} / \mathrm{min}$ shows inhibition activity in the presence of inhibitory molecule(s) in protein samples. 540 is the molar extinction co-efficient of TAME at $247 \mathrm{~nm}$.

Chymotrypsin inhibition assay: Chymotrypsin inhibition activity was determined using $1 \mathrm{mM}$ synthetic substrate $\mathrm{N}$ Benzoyl L-tyrosine ethyl ester (BTEE). $100 \mu \mathrm{L}$ of crude extract, $30 \%, 60 \%$ and saturated ammonium sulphate (AS) fractions $(1 \mathrm{mg} / \mathrm{mL})$ were added to $650 \mu \mathrm{L}$ of assay buffer was mixed with $100 \mu \mathrm{L}$ of chymotrypsin $(20 \mu \mathrm{g} / \mathrm{ml})$ solution and left for $12 \mathrm{~min}$ at RT. $250 \mu \mathrm{L}$ of substrate was added to preincubated contents, mixed quickly and absorbance was immediately monitored at $256 \mathrm{~nm}$ for 4 minutes. Soybean trypsin inhibitor was used as positive control. Chymotrypsin inhibitor activity was calculated as chymotrypsin inhibition units (CIU) per milligram of extract as follows

$$
\mathrm{CIU} / \mathrm{mg}=\frac{\left[\left(\frac{\mathrm{T} \Delta \mathrm{A} 256}{\mathrm{~min}}-\frac{\mathrm{I} \Delta \mathrm{A} 256}{\min }\right) \times 1000\right]}{964 \mathrm{x} \text { protein content }(\mathrm{mg})}
$$

964 is the molar extinction co-efficient of BTEE at $256 \mathrm{~nm}$.

Dipeptidyl pedptidase-IV inhibition assay: DPP-IV inhibitiory activity of protein extracts was screened by using method of Al masri et al., (2009) with little modifications. Serine protease, DPP-IV cleaves chromogenic substrate to release yellow colored product i.e., paranitroaniline (pNA) which is measured at $405 \mathrm{~nm}$. Diprotin A, a tripeptide was used as positive control. Sample solution containing $100 \mu \mathrm{g}$ protein content were mixed with reaction buffer ( $50 \mathrm{mM}$ Tris, $\mathrm{pH} 7.5)$ to make volume upto $151 \mu \mathrm{L}$ then $24 \mu \mathrm{L}$ of DPP-IV suspension $(0.05 \mathrm{mU} / \mu \mathrm{L})$ were added, mixed briefly and preincubated for 30 minutes at $37{ }^{\circ} \mathrm{C}$. $25 \mu \mathrm{L}$ of chromogenic substrate (Gly-Pro-nitroanilide, $1.59 \mathrm{mM}$ ) were added and incubated for 30 minutes at $37{ }^{\circ} \mathrm{C}$ followed by measurement of absorbance at $510 \mathrm{~nm}$ after termination of reaction with 25 $\mu \mathrm{L}$ of $25 \%$ glacial acetic acid. Control was prepared by replacing extracts with buffer and no enzyme was added to blank reaction, instead volume was made up with buffer. Inhibitory activity was expressed as percent inhibition

$$
\% \text { Inhibition }=\frac{O D_{\text {control }}-O D_{\text {inhibitor }}}{O D_{\text {control }}} \times 100
$$

Angiotensin converting enzyme (ACE) inhibition assay: ACE inhibition assay was carried out by following method of
Adjonu et al., (2013) with few modifications. $30 \mu \mathrm{L}$ of protein extracts $(2 \mathrm{mg} / \mathrm{ml})$ or buffer (in control and blank reactions) were incubated with $10 \mu \mathrm{L} \mathrm{ACE}(0.25 \mathrm{U} / \mathrm{ml})$ for $5 \mathrm{~min}$ at 37 ${ }^{\circ} \mathrm{C}$ in 96 well microplate. No enzyme was added to wells containing blank reactions. $150 \mu \mathrm{L}$ of $0.88 \mathrm{mM}$ substrate FAPGG, (N-(3-(2-Furyl)acryloyl)-L-phenylalanyl-glycylglycyl-glycine) was added and reaction was monitored for 50 min at $340 \mathrm{~nm}$.to observe decrease in absorbance of reaction due to degradation of FAPGG. Captopril was used as positive control. Percent inhibition was calculated using formula

$$
\% \text { Inhibition }=\frac{\mathrm{OD}_{\text {control }}-\mathrm{OD}_{\text {inhibitor }}}{\mathrm{OD}_{\text {control }}} \times 100
$$

\section{RESULTS}

Effect of Extraction Medium on Solubility of Inhibitor: Three different aqueous solvents were used to extract proteins with inhibitory activity against serine proteases from Nigella sativa defatted seed flour $(1: 10 \mathrm{w} / \mathrm{v})$ (Figure 1$)$. Inhibitory activity of soluble extract prepared in $50 \mathrm{mM}$ Tris buffer $\mathrm{pH}$ 8 was highest against trypsin, whereas chymotrypsin inhibitory activity was not measurable. Soluble protein content $(4.19 \pm 0.45 \mathrm{mg} / \mathrm{mL})$ of Tris buffer extract was lower than that of $\mathrm{NaOH}$ soluble extract $(6.6 \pm 0.6 \mathrm{mg} / \mathrm{mL})$. Although protein content of $100 \mathrm{mM} \mathrm{NaOH}$ soluble extract was highest it did not show any measurable inhibition. On the contrary, little inhibitory activity was observed in $50 \mathrm{mM}$ Acetic acid soluble extract containing lowest protein content $1.89 \pm 0.23 \mathrm{mg} / \mathrm{mL}$ (Figure 2, 3). Apparently, no relation was observed between protein content and inhibitory activity of extracts.

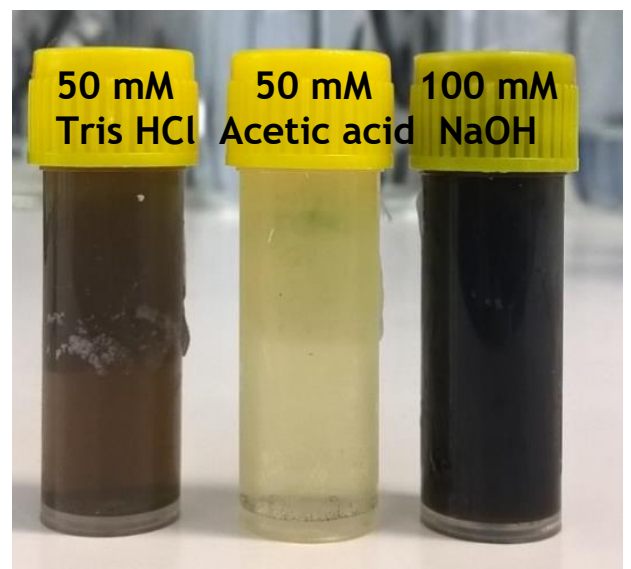

Figure 1.Nigella sativa crude extracts prepared from defatted seed powder by using different aqueous solvents.

Effect of Temperature and Extraction Time on Solubility of Inhibitor: Extraction of highest inhibitory content was achieved by using $50 \mathrm{mM}$ Tris $\mathrm{HCl} \mathrm{pH} \mathrm{8.} \mathrm{This} \mathrm{extraction}$ buffer was then used to evaluate effect of temperature and 
duration of extraction on inhibitory protein content of extracts. It was found that there was no significant difference between inhibitory content of extracts incubated at room temperature and $4^{\circ} \mathrm{C}$ for 5 hours. On the contrary, extraction of seed flour overnight at $4{ }^{\circ} \mathrm{C}$ was found to have more active inhibitory content than extraction carried out overnight at room temperature. (Figure 4).

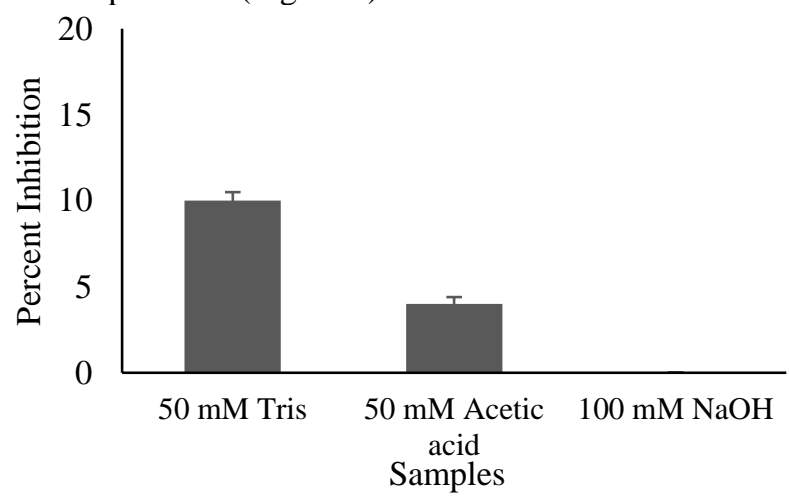

Figure 2. Effect of different aqueous solvents on inhibitory activity of $N$. sativa crude extracts against trypsin.

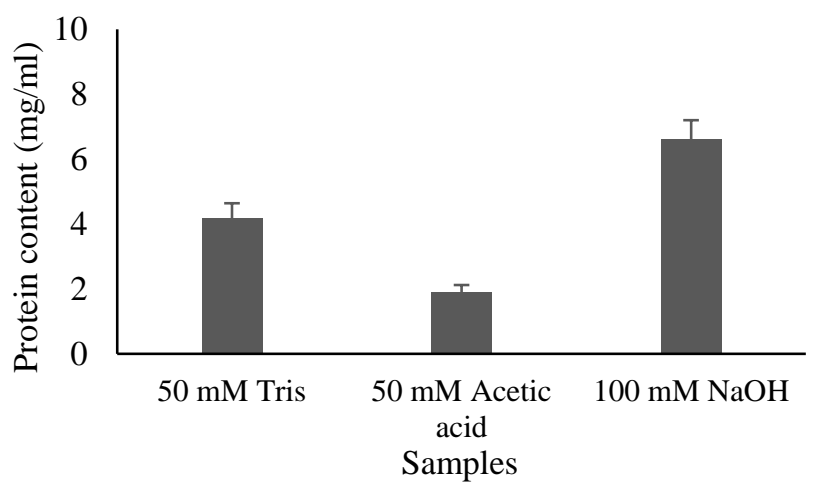

Figure 3. Effect of different aqueous solvents on soluble protein content of $N$. sativa defatted seed powder crude extracts.

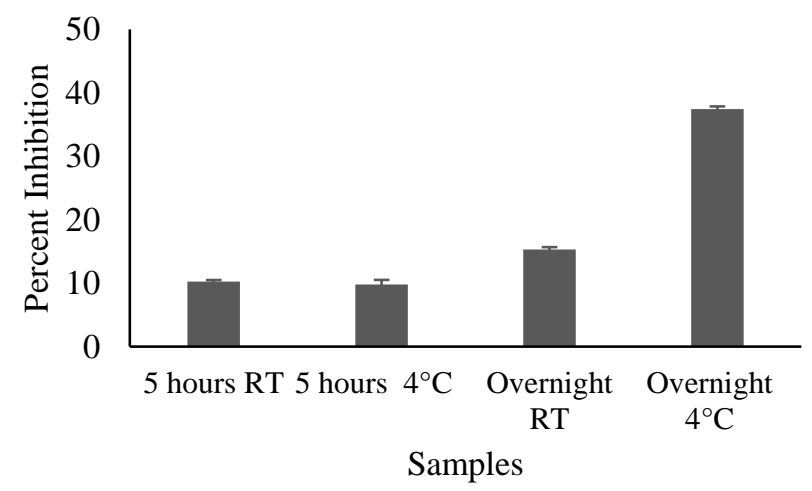

Figure 4. Effect of temperature and extraction time on inhibitory contents of crude extracts of defatted Nigella sativa powdered seeds.
In vitro Trypsin Inhibition: Trypsin and chymotrypsin inhibition assays carried out to assess protease inhibitory activity revealed that only crude extract and AS-60 fraction were active against trypsin (Figure 5), however, none of these fractions showed detectable chymotrypsin inhibition activity. Trypsin inhibitory activity of AS-60 was comparable to SBTI. It showed $60.15 \pm 2.95 \%$ inhibition of trypsin. However, crude extract exhibited $10.54 \pm 1.76 \%$ inhibition of trypsin. Low content of trypsin inhibitor in crude extract suggests that $N$. sativa seeds are safe for human and animal consumption as high concentrations of trypsin inhibitors interfere with digestive enzymes (Belitz and Weder, 1990).

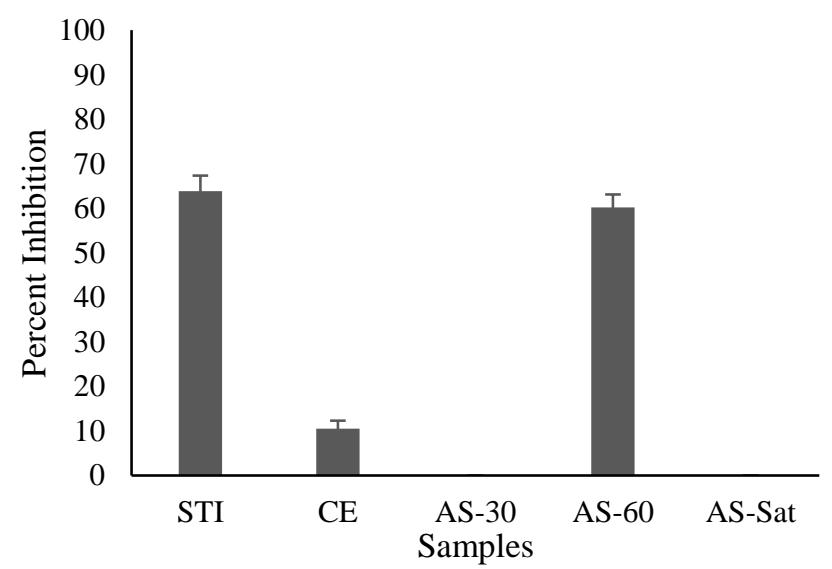

Figure 5. Inhibitory effects of Nigella sativa protein extracts on trypsin activity. Samples: (STI) Soybean trypsin inhibitor, (CE) crude extract $30 \%$ ammonium sulphate precipitated fraction (AS-30), 60\% ammonium sulphate precipitated fraction (AS-60), saturated ammonium sulphate precipitated fraction (AS-Sat).

Partial purification of trypsin inhibitor(s) was achieved by ammonium sulphate precipitation of crude extract at $60 \%$ saturation and dialysis. Purification process of trypsin inhibitor along with percent recovery and fold purification has been summarized in Table 1 . The crude water extract showed very low specific activity of $0.06 \mathrm{TIU} \mathrm{mg}^{-1}$. However, Ammonium sulphate precipitated fractions AS-30 and ASSat. did not exhibit any noticeable trypsin inhibitory activity. AS-60 had a noticeably increased specific activity of $2.39 \pm 0.23 \mathrm{TIU} \mathrm{mg}^{-1}$ with 39.83 fold purification and protein recovery of only $25.71 \%$.

ACE and DPPI-IV inhibition studies: Crude extract and all the three fractions of Nigella sativa seed proteins (AS-30, AS60 and AS-Sat.) showed in vitro DPPI-IV and ACE inhibitory activity, though DPPI-IV inhibition was not comparable to ACE inhibition. Crude extract of $N$. sativa exhibited about $89 \%$ inhibition of angiotensin converting enzyme. When crude extract was separated into three fractions AS-30, AS-60 and AS-Sat., only two fractions (AS-30 and aS-60) were found active against ACE with $61 \%$ and $29 \%$ inhibitory 
Anti-trypsin and antihypertensive activity of protein

Table 1. Yield of protein and protease inhibitor activity of crude extract and Ammonium sulphate fractions.

\begin{tabular}{lccccc}
\hline Purification step & $\begin{array}{c}\text { Total protein } \\
(\mathbf{m g})\end{array}$ & Total activity $(\mathbf{U})$ & $\begin{array}{c}\text { Specific activity } \\
(\mathbf{U} / \mathbf{m g})\end{array}$ & $\begin{array}{c}\text { Yield of Protein } \\
\mathbf{\%}\end{array}$ & Fold purification \\
\hline Crude Extract & $2100.84 \pm 5.25$ & 115.52 & $0.06 \pm 0.01$ & 100.00 & 1.00 \\
$0-30 \%$ AS & $654.00 \pm 4.50$ & Not detectable & - & - & - \\
$30-60 \%$ AS & $540.76 \pm 1.53$ & 13003.41 & $2.39 \pm 0.23$ & 25.71 & 39.83 \\
$60-100 \%$ AS & $320.00 \pm 2.10$ & Not detectable & - & - & - \\
\hline
\end{tabular}

activity, however inhibition displayed by these two fractions was less than that of crude extract (Figure 6).

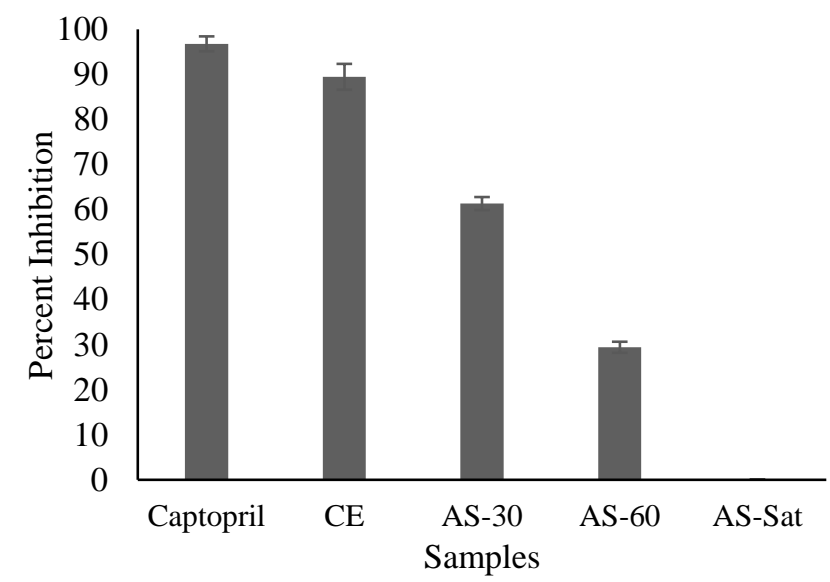

Figure 6. Inhibitory effects of Nigella sativa protein extracts on activity of ACE (angiotensin converting enzyme). Samples: crude extract (CE), $30 \%$ ammonium sulphate precipitated fraction (AS-30), $60 \%$ ammonium sulphate precipitated fraction (AS-60), saturated ammonium sulphate precipitated fraction (ASSat).

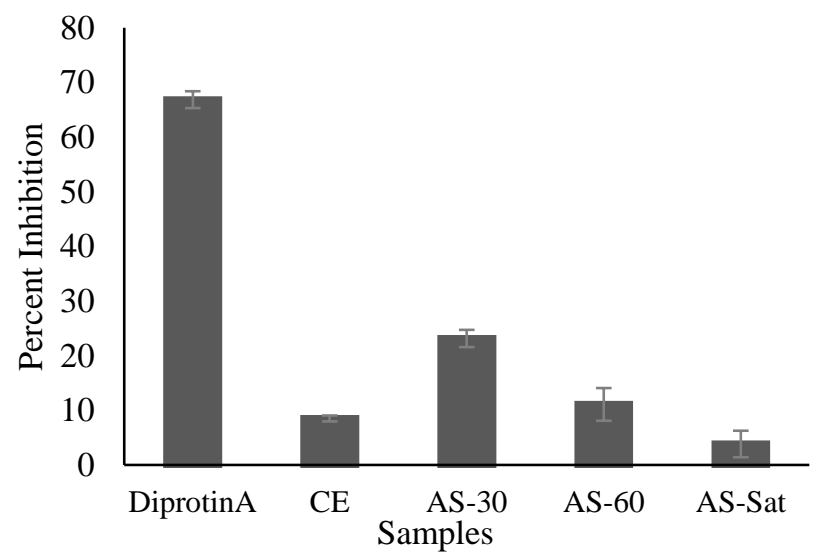

Figure 7.Inhibitory effects of Nigella sativa protein extracts on activity of DPPI-IV. Samples: crude extract (CE), 30\% ammonium sulphate precipitate fraction (AS-30), 60\% ammonium sulphate precipitate fraction (AS-60), saturated ammonium sulphate precipitate fraction (AS-Sat).
Figure 7 shows percent inhibition of different fractions of $N$. sativa subjected to DPPI-IV inhibition assay. None of the fractions exhibited DPPI-IV inhibitory activity comparable to positive control Diprotin A though AS-60 inhibited another member of serine protease i.e., trypsin comparable to positive control soybean trypsin inhibitor. AS-30 fraction appeared to be highly active against DPPI-IV showing 23\% inhibition. AS-60, crude extract and AS-Sat. expressed $11 \%, 8.5 \%$ and $3.8 \%$ inhibition of DPPI-IV.

\section{DISCUSSION}

PIs have been widely studied from many plant families focusing on their agricultural applications based on pest control (Green and Ryan, 1972; Joshi et al., 2014; Pannetier et al., 1997; Vain et al., 1998). More and more plant sources are being explored by biological researchers in search of diverse protein molecules. In this scenario, underexplored plant families represent a good opportunity to investigate novel proteins with greater potential for controlling phytopathogens and pests improving agricultural yield. Therapeutic potential of several trypsin inhibitors also has been reported in various studies (Islamov and Fursov, 2007; Troncoso et al., 2007). Trypsin inhibitors isolated from various plants have exhibited anticarcinogenic and antiproliferative activities (Armstrong et al., 2000). Therefore, role of trypsin inhibitors is suggested to be important for agricultural as well as clinical applications.

In this study, we have screened trypsin inhibitor(s) from $N$. sativa seeds. This is first report to the best of our knowledge revealing partial purification of trypsin inhibitor proteins from $N$. sativa seeds. The conditions were optimized to extract trypsin inhibitor from $N$. sativa seeds. Based on our results, extraction of proteins with maximum trypsin inhibitory activity was achieved by suspending defatted seed flour in 50 $\mathrm{mM}$ Tris buffer $\mathrm{pH} 8$ for longer time period (overnight) at lower temperature $\left(4^{\circ} \mathrm{C}\right)$. Tris buffer has been commonly used in plant proteomics studies as a suitable buffer for extraction of proteins (Fan et al., 2016; Shamsi et al., 2016). Presence of endogenous proteases affect stability of proteins which could be avoided by carrying out extraction at lower temperatures (Janson, 2012). Heat treatment of protein preparation might result in reduction or loss of inhibitory activity (Liener, 2005). Trypsin inhibitory protein was partially purified from $N$. sativa seeds by ammonium sulphate precipitation. Sixty 
percent AS saturation (AS-60) was found to be efficient for precipitating trypsin inhibitory proteins and the enrichment was 39.83 folds, which is relatively higher than what is reported for other plant species (Abd El-latif, 2015; Bacha et al., 2017).

Natural products have been used as therapeutic agents by humans from ancient times. Plants are the major source of these natural products being used for curing and preventing various diseases by common people. Bio-active compounds isolated from medicinal plants have less or no side effects, therefore, are strong candidates for potential drug therapies (Croteau et al., 2000). Enzyme inhibition has largely become an important therapeutic approach against a number of diseases. Enzymes are potential targets to cure metabolic disorders as they play essential role in metabolism (Viollet et al., 2009).

Inhibition of proteases such as ACE and DPPI-IV is a beneficial therapeutic approach for the treatment of high blood pressure and diabetes (Kamath et al., 2007; Mendeinta et al., 2011). Studies conducted on evaluation of $N$. sativa seed powder, essential oil, aqueous and non-aqueous extracts and its main component thymoquinone have showed pronounced therapeutic effects in different disorders (Gholamnezhad et al., 2016). Therefore, its protein repertoire was evaluated for bioactive potential against two important proteases playing key physiological roles in the control of blood pressure and diabetes. Hypertension and diabetes are closely related diseases (Leet et al., 2017). There is higher prevalence of high blood pressure in diabetic patients (Type I $\&$ II) than in individuals without diabetes (Cheung, 2010). Coincidence of hypertension and diabetes is more common in people with type II diabetes (Reavan et al., 1990). Similarly, development of diabetes has also been associated with prehypertension and hypertension (Kim et al., 2015). Therefore, controlling one factor either diabetes or blood pressure in individuals could lessen the chances of predisposition to the other one.

In the light of results obtained from current study it is suggested that $N$. sativa seeds are potential source of bioactive proteins. Crude extract of $N$. sativa seeds was more efficient in terms of antihypertensive activity compared to AS protein fractions. This could be due to presence of other water-soluble compounds in crude extract contributing towards its high inhibitory activity against angiotensin converting enzyme. Synergy among the number of bioactive compounds present in whole grains makes them greater than the sum of fractions in terms of their health benefits (Slavin, 2003).

Conclusively, our results demonstrate potent in vitro antitrypsin and antihypertensive activity of seed proteins from $N$. sativa, widely used as traditional medicine to cure various ailments in several countries including Southeast Asia. However, in vivo studies are required to validate results of in vitro assays. Research is continued on purification and characterization of trypsin inhibitor as well as its health benefits.

\section{REFERENCES}

Abbenante, G. and Fairlie, D.P. 2006. Protease Inhibitors in the Clinic. Med. Chem. 1:71-104.

El-latif, A.O.A. 2015. Biopotency of serine protease inhibitors from cowpea (Vigna unguiculata) seeds on digestive proteases and the development of Spodoptera littoralis (Boisduval). Arch. Insect. Biochem. Physiol. $1: 1-17$.

Adjonu, R., Doran, G., Torley, P. and Agboola, S. 2013. Screening of whey protein isolate hydrolysates for their dual functionality: Influence of heat pre-treatment and enzyme specificity. Food Chem. 136:1435-1443.

Ahmad A, Husain A, Mujeeb M., Khan, S.A., Najimi, A.K., Siddique, N.A., Damanhouri, Z.A. and Anwar, F. 2013. A review on therapeutic potential of Nigella sativa: A miracle herb. Asian Pac. J. Trop. Biomed. 3:337-352.

Al-Masri, I.M., Mohammad, M.K. and Tahaa, M.O. 2009. Inhibition of dipeptidyl peptidase IV () is one of the mechanisms explaining the hypoglycemic effect of berberine. J. Enzyme Inhib. Med. Chem. 24:1061-1066.

Armstrong, W.B., Kennedy, A.R., Wan, X.S., Atiba, J., McLaren, C.E. and Myskens, F.L. 2000. Single-dose administration of Bowman-Birk inhibitor concentrate in patients with oral leukoplakia. Cancer Epidemiol. Prev. Biomarkers. 9:43-47.

Bacha, A.B., Jemel, I., Moubayed, N.M.S. and Abdelmalek, I.B. 2017. Purification and characterization of a newly serine protease inhibitor from Rhamnus frangula with potential for use as therapeutic drug. 3 Biotech. 7:148.

Belitz, H.D. and Weder, J.K.P. 1990. Protein inhibitors of hydrolases in plant foodstuffs. Food Rev. Int. 6:151-211.

Cheung, B.M.Y. 2010. The hypertension-diabetes continuum. J Cardiovasc. Pharmacol. 55:333-339.

Christeller, J.T. 2005. Evolutionary mechanisms acting on proteinase inhibitor variability. FEBS J. 272:5710-5722.

Croteau, R., Kutchan, T.M., Lewis, N.G. 2000. Natural Products (Secondary Metabolites). In: B.B. Buchanan, W. Gruissem and R.L. Jones (eds.), Biochemistry and Molecular Biology of Plants. American Society of Plant Physiologists, Rockville, Maryland. pp.1250-1318.

Leo, F.D., Volpicella, M., Licciulli, F., Liuni, S. Gallerani, R. and Ceci, L.R. 2002. PLANT-PIs: a database for plant protease inhibitors and their genes. Nucleic Acids Res. 30:347-348.

Di Cera, E. 2009. Serine proteases. IUBMB Life. 61:510-515.

Fan S.G., Guo-Jiang, W.U. 2005. Characteristics of plant proteinase inhibitors and their applications in combating phytophagous insects. Bot. Bull. Acad. Sin. 46. 
Fan, T., Bykova, N.V., Rampitsch, C. and Xing, T. 2016. Identification and characterizayion of a serine protease from wheat leaves. Eur. J. Plant Pathol. 146:283-304.

Gholamnezhad, Z., Havakhah, S. and Boskabady, M.H. 2016. Preclinical and clinical effects of Nigella sativa and its constituent, thymoquinone: A review. J. Ethnopharmacol. 190:372-386.

Green, T.R. and Ryan, C.A. 1972. Wound-induced proteinase inhibitor in plant leaves: a possible defense mechanism against insects. Science. 175:776-777.

Islamov, R.A. and Fursov, O.V. 2007. Bifunctional inhibitor of [alpha]-amylase/trypsin from wheat grain. Appl. Biochem. Microbiol. 43:379-382.

Janson, J.C. 2012. Protein purification: principles, high resolution methods, and applications, Vol. 151. John Wiley \& Sons, New York.

Johnson, S.L. and Pellecchia, M. 2006. Structure- and fragment-based approaches to protease inhibition. Curr. Top. Med. Chem. 6:317-329.

Joshi, R.S., Gupta, V.S. and Giri, A.P. 2014. Differential antibiosis against Helicoverpa armigera exerted by distinct inhibitory repeat domains of Capsicum annuum proteinase inhibitors. Phytochemistry. 101:16-22.

Kamath, V., Niketh, S., Chandrashekar, A. and Rajini, P.S. 2007. Chymotryptic hydrolysates of $\alpha$-kafirin, the storage protein of sorghum (Sorghum bicolor) exhibited angiotensin converting enzyme inhibitory activity. Food Chem. 100:306-311.

Kidrič, M., Kos, J. and Sabotič, J. 2014. Proteases and their endogenous inhibitors in the plant response to abiotic stress. Bot. Serb. 38:139-158.

Kim, M.J., Lim, N.K., Choi, S.J. and Park, H.Y. 2015. Hypertension is an independent risk factor for type 2 diabetes: The Korean genome and epidemiology study. Hypertens. Res. 38:783.

Kollipara, K.P. and Hymowitz, T. 1992. Characterization of trypsin and chymotrypsin inhibitors in the wild perennial Glycine species. J. Agric. Food Chem. 40:2356-2363.

Laskowski, J. M. and Kato, I. 1980. Protein inhibitors of proteinases. Annu. Rev. Biochem. 49:593-626.

Lee, S.W., Kim, H.C. and Lee, J.M., Yun, Y.M., Lee, J.Y. and Suh, I. 2017. Association between changes in systolic blood pressure and incident diabetes in a communitybased cohort study in Korea. Hypertens. Res. 40:710.

Liener, I.E. 2005. Toxic constituents of plant foodstuffs. Proc. Nutr. Soc. 29:56-57.

Mendieta, L., Tarrago, T. and Giralt, E. 2011. Recent patents of dipeptidyl peptidase IV inhibitors. Expert. Opin. Ther. Pat. 21:1693-1741.
Meulenbroek, E.M., Thomassen, E.A.J., Pouvreau, L., Abrahams, J.P., Gruppen, H. and Pannu, N.S. 2012. Structure of a post-translationally processed heterodimeric double-headed Kunitz-type serine protease inhibitor from potato. Acta Crystallogr. Sect. D. Biol. Crystallogr. 68:794-799.

Pannetier, C., Giband, M., Couzi, P., Le Tan, V., Mazier, M., Tourneur, J. and Hau, B. 1997. Introduction of new traits into cotton through genetic engineering: insect resistance as example. Euphytica. 96:163-166.

Polya, G.M. 2003. Protein and non-protein protease inhibitors from plants. Stud. Nat. Prod. Chem. 29:567-641.

Reaven, P.D., Barrett-Connor, E.L. and Browner, D.K. 1990. Abnormal glucose tolerance and hypertension. Diabetes Care. 13:119-125.

Reppond, K.D. and Babbitt, J.K. 1993. Protease Inhibitors Affect Physical Properties of Arrowtooth Flounder and Walleye Pollock Surimi. J. Food Sci. 58:96-98.

Ryan, C.A. 1990. Protease inhibitors in plants: genes for improving defenses against insects and pathogens. Annu. Rev. Phytopathol. 28:425-449.

Slavin, J. 2003. Why whole grains are protective: biological mechanisms. Proc Nutr Soc. 62: 129-134.

Slavokhotova, A.A., Naumann, T.A., Price, N.P.J., Rogozhin, E.A., Andreev, Y.A., Vassilevski, A.A. and Odintsova, T.I. 2014. Novel mode of action of plant defense peptides-hevein-like antimicrobial peptides from wheat inhibit fungal metalloproteases. FEBS J. 281:4754-4764.

Shamsi, T.N., Perveen, R., Amir, A., Baig, M.A., Qureshi, M.I, Ali, S. and Fatima, S. 2016. Allium sativum protease inhibitor: a novel Kunitz trypsin inhibitor from garlic is a new comradeof the serpin family. Plos one. 11:1-16.

Troncoso, M.F., Biron, V.A., Longhi, S.A., Retegui, L.A. and Wolfenstein-Todel, C. 2007. Peltophorum dubium and soybean Kunitz-type trypsin inhibitors induce human Jurkat cell apoptosis. Int. Immunopharmacol. 7:625-636.

Vain, P., Worland, B., Clarke, M.C., Richard, G., Beavis, M., Liu, H., Kohli, A., Leech, M., Snape, J., Christou, P. and Atkinson, H. 1998. Expression of an engineered cysteine proteinase inhibitor (Oryzacystatin-I $\Delta$ D86) for nematode resistance in transgenic rice plants. Theor. Appl. Genet. 96:266-271.

Vierstra, R.D. 1996. Proteolysis in plants: mechanisms and functions. In: Post-Transcriptional Control of Gene Expression in Plants. Springer, Dordrecht. Pp. 275-302.

Viollet, B. 2009. Targeting the AMPK pathway for the treatment of Type 2 diabetes. Front. Biosci. 14:3380. 